\title{
PRODUKSI OLEORESIN BERBAHAN BAKU LIMBAH DESTILASI KAYU MANIS (Cinnamomum burmannii)
}

\author{
OLEORESIN PRODUCTION MADE FROM RAW SEWAGE DISTILLATION of CINNAMON \\ (Cinnamomum burmannii) \\ Dimas Nurcahyo Adi ${ }^{(1)}$, Lia Umi Khasanah ${ }^{(1)}$, Baskara Katri Anandito(1) \\ ${ }^{(1)}$ Prodi Ilmu dan Teknologi Pangan Universitas Sebelas Maret \\ Jl. Ir. Sutami 36A Surakarta \\ email : liaumikhasanah@yahoo.co.id
}

\begin{abstract}
This research aimed to find out the condition of optimum yield in the process of producing raw sewage distillation of cinnamon oleoresin in the variations of material size, temperature, and contact time during maceration extraction process and to find out the characteristics of cinnamon oleoresin including cinnamaldehyde, cinnamon oil content, and solvent residue (methanol) levels. This research used the variations of material size (20,50, and 80 mesh), extraction temperature $\left(45,55\right.$, and $\left.65^{\circ} \mathrm{C}\right)$, and extraction time $(2,4,6$ hours). Data is processed using Response Surface Methodology (RSM) and the equation of optimum yield of cinnamon oleoresin was knowed as : $Y=11.1756+0.2344 X_{1}+0.5271 X_{2}+0.0453 X_{3}+1.2718 X_{1}^{2}+0.9178 X_{2}^{2}-$ $0.2200 X_{3}^{2}+0.1600 X_{1} X_{2}-0.6858 X_{1} X_{3}-0.5947 X_{2} X_{3}$. The optimum yield of cinnamon oleoresin was found 11.137 $\%$ obtained on the condition of 50.267 mesh particle size, temperature $53.199^{\circ} \mathrm{C}$, andextraction time4.265hours. Cinnamon oleoresin quality characteristics at the optimum yield included levels of sinamaldehid 12.22\%, volatile oil content $7.554 \%$ and thelevels of residual solvent (methanol content) $1.66 \mathrm{ppm}$.
\end{abstract}

Keywords: cinnamon, oleoresin of cinnamon, optimization of yield, quality characteristics oleoresin of cinnamon.

\section{ABSTRAK}

Penelitian ini bertujuan untuk mengetahui rendemen optimum dalam proses produksi oleoresin limbah destilasi kulit kayu manis pada berbagai variasi ukuran partikel, suhu dan waktu kontak selama proses ekstraksi maserasi dan mengetahui karakteristik mutu oleoresin limbah destilasi kulit kayu manis yang meliputi kadar sinamaldehid, kadar minyak atsiri, dan kadar sisa pelarut (kadar metanol). Penelitian ini menggunakan variasi ukuran bahan $\left(20,50\right.$, dan 80 mesh), suhu ekstraksi $\left(45,55,65^{\circ}\right)$, waktu kontak $(2,4,6$ jam). Pengolahan data menggunakan Response Surface Methodology (RSM) diketahui persamaan optimasi rendemen oleoresin limbah destilasi kayu manis yaitu : $\mathrm{Y}=11,1756+0,2344 \mathrm{X}_{1}+0,5271 \mathrm{X}_{2}+0,0453 \mathrm{X}_{3}+1,2718 \mathrm{X}_{1}{ }^{2}+0,9178 \mathrm{X}_{2}{ }^{2}-0,2200 \mathrm{X}_{3}{ }^{2}$ $+0,1600 X_{1} X_{2}-0,6858 X_{1} X_{3}-0,5947 X_{2} X_{3}$. Rendemen optimum oleoresin yang diperoleh sebesar $11,137 \%$ yang didapat pada ukuran partikel sebesar 50,267 mesh, suhu ekstraksi $53,199^{\circ} \mathrm{C}$, dan waktu ekstraksi 4,6652 jam. Karakteristik mutu oleoresin limbah destilasi kayu manis pada rendemen optimum adalah kadar sinamaldehid $12,22 \%$, kadar minyak atsiri 7,554 \% dan kadar sisa pelarut ( kadar metanol ) 1,66 ppm.

Kata kunci: karakteristik mutu oleoresin limbah destilasi kulit kayu manis, kulit kayu manis, oleoresin limbah destilasi kulit kayu manis, optimasi rendemen

\section{PENDAHULUAN}

Kayu manis merupakan salah satu tanaman khas Indonesia dan banyak tumbuh di daerah pegunungan. Bagian tanaman yang dapat dikomersialkan terutama adalah kulit kayu (Cassiavera). Produk ini memiliki aroma dan rasa khas sehingga digolongkan ke dalam rempah-rempah eksotis dari timur (citarasa oriental). Dalam dunia perdagangan, menurut Purseglove et al., (1987); Rismunandar dan Farry (2001) dalam Wuri et al., (2004) ada beberapa jenis kulit kayu manis yang dikenal, diantaranyajenis Cinnamomum verum berasal dari Sri Lanka dan Madagaskar, Cinnamomum cassia dari Cina, Vietnam, India dan Nepal, Cinnamomum camphora dari Jepang dan Taiwan, dan juga jenis Cinnamomum burmanni Blume (cassivera) yang ada di Indonesia.

Menurut Sundari (2002), pada tahun 1991, sekitar 94,1\% cassiaveradi dunia didominasi oleh Cinnamomum burmannii blume dari Indonesia sedangkan sisanya 4,2 $\%$ dari Srilanka.Tetapi selama ini Indonesia masih mengekspornya dalam bentuk gulungan kulit kayu manis (quill) yang mempunyai nilai ekonomi masih rendah. Teknologi pengolahan kulit kayu manis 
menjadi produk minyak kulit kayu manis dan oleoresin merupakan langkah yang baik dalam meningkatkan nilai ekonomis kayu manis.

Menurut Cripps, (1973) dalam Sulaswatty et al., (2001)oleoresin merupakan produk yang dapat dihasilkan dari ekstraksi kulit kayu manis, dimana produk ini memiliki kelebihan dibandingkan dengan penggunaan rempah-rempah mentah dikarenakan lebih ekonomis, lebih mudah dikontrol dan lebih bersih. Selain itu,kelebihan utama dibandingkan dengan penggunaan minyak atsiri adalah flavor lengkap dan stabil terhadap panas selama pengolahan.

Komponen kimia oleoresin dipengaruhi oleh jenis bahan tanaman dan pelarut yang digunakan. Aroma dan cita rasa oleoresin ditentukan oleh senyawa mudah menguap dan senyawa yang tidak mudah menguap. Senyawa penting yang terdapat dalam oleoresin adalah karotenoid, curcuminoid, phenolic,aldehid dan lain-lain (Sundari, 2002).Oleoresin dalam industri pangan banyak digunakan sebagai pemberi cita rasa dalam produk-produk olahan daging (misalnya sosis, burger, kornet), ikan dan hasil laut lainnya, roti, kue, puding, sirup, saus dan lain-lain.Sementara itu industri es krim, permen, biskuit dan lain-lain membutuhkan kayu manis dalam bentuk yang mudah digunakan dan lebih seragam.

Pengambilan oleoresin kayu manis menggunakan cara ekstraksi.Ekstraksi adalah metode untuk memisahkan suatu komponen dari campuran dengan menggunakan solvent/pelarut.Teknik ekstraksi oleoresin dalam bahan rempah-rempah adalah tehnik ekstraksi cair-cair dan ekstraski cair-padat. Faktor-faktor yang mempengaruhi laju ekstraksi, yaitu: ukuran partikel, pelarut, suhu, dan pengadukan dari fluida (campuran pelarut, solute, dan padatan).

Pada penelitian ini kulit kayu manis yang akan digunakan untuk proses ekstraksi, terlebih dahulu diberi perlakuan destilasi untuk memisahkan minyak atsirinya, hal tersebut dilakukan untuk menyesuaikan terhadap permintaan pasar.Selain daripada hal tersebut kandungan minyak atsiri dalam oleoresin yang diperoleh nantinya tentu saja harus sesuai dengan standar yang berlaku, yang termuat dalam Food Drug Administration (FDA) yang menyatakan bahwa salah satu spesifikasi oleoresinadalah memiliki kandunganminyak atsiri minimal 25 $\%$. Kemudian akan dikaji karakteristik mutu oleoresin limbah destilasi kulit kayu manis yang diperoleh dan kadar sinamaldehid yang paling optimal dengan menggunakan variasi suhu, ukuran bahan, waktu kontak.

\section{METODE PENELITIAN}

\section{Bahan dan Alat}

Bahan yang digunakan dalam penelitian ini adalah limbah destilasi kayu manis (Cinnamomum burmannii) yang diperoleh dari daerah wonogiri. Dalam proses ekstraksi limbah destilasi kayu manispelarut yang digunakan adalah pelarut metanol. Sedangkan bahan-bahan yang digunakan untuk analisis antara lain analisis kadar minyak atsiri mnggunakan aquadest dan xylol, dan analisis kadar sinamaldehid menggunakan pelarut dietil eter.

Alat yang digunakan dalam proses pembuatan oleoresin limbah destilasi kayu manis adalah cabinet dryer, mesin penepungan, ayakan 20;50; 80 mesh, labu leher tiga, hot plate. pendingin balik, rotary evaporator vacum, pipet, corong, gelas ukur, bekker glass, pompa vakum, kertas saring. Sedangkan alat-alat yang digunakan untuk analisis antara lain timbangan analitik, oven, satu set lengkap instrumen gas kromatografi (GC-MS) tipe QP 2010, labu destilasi, pendingin balik, hot plate, pipet, gelas ukur, tabung elenmeyer, dan satu set lengkap instrument kromatografi gas (GC).

\section{Tahapan Penelitian}

Kayu manis sisa destilasi ditepungkan dengan menggunakan mesin penepung untuk menghasilkan bubuk kulit kayu manis. Selanjutnya bubuk kulit kayu manis diayak dengan menggunakan mesin pengayak. Sehingga didapatkan bubuk kulit kayu manis berukuran 20, 50 dan 80 mesh. Kemudian dilakukan ekstraksi maserasi menggunakan labu leher tiga pada variasi suhu $\left(45^{\circ} \mathrm{C}, 55^{\circ} \mathrm{C}\right.$, dan $\left.65^{\circ} \mathrm{C}\right)$ dan waktu kontak $(2,4$, dan 6 jam). Pelarut yang digunakan dalam proses ekstraksi bubuk limbah destilasi kulit kayu 
Tabel 1 Kode dan Tak kode untuk Kombinasi RSM

\begin{tabular}{lcccc}
\hline \multicolumn{1}{c}{ Variabel } & Kode (X) & \multicolumn{3}{c}{ Kode Level } \\
\cline { 3 - 5 } & & -1 & 0 & +1 \\
\cline { 3 - 5 } & & \multicolumn{3}{c}{ Tak Kode } \\
Ukuran(mesh) & $\mathrm{X} 1$ & 20 & 50 & 80 \\
Suhu ( ${ }^{\circ}$ C) & $\mathrm{X} 2$ & 45 & 55 & 65 \\
Waktu (jam) & $\mathrm{X} 3$ & 2 & 4 & 6 \\
\hline
\end{tabular}

Tabel 2 Desain Penelitian Box-Benhken

\begin{tabular}{cccc}
\hline Run & X1 & X2 & X3 \\
\hline 1 & -1 & -1 & 0 \\
2 & -1 & 1 & 0 \\
3 & 1 & -1 & 0 \\
4 & 1 & 1 & 0 \\
5 & -1 & 0 & -1 \\
6 & -1 & 0 & 1 \\
7 & 1 & 0 & -1 \\
8 & 1 & 0 & 1 \\
9 & 0 & -1 & -1 \\
10 & 0 & -1 & 1 \\
11 & 0 & 1 & -1 \\
12 & 0 & 1 & 1 \\
13 & 0 & 0 & 0 \\
14 & 0 & 0 & 0 \\
15 & 0 & 0 & 0 \\
\hline
\end{tabular}

manis adalah metanol dengan perbandingan 1: 6 dengan berat bahan 60 gr. Setelah proses ekstraksi selesai kemudian dilakukan penyaringan, bertujuan untuk memisahkan antara ampas (endapan) dan filtrat. Kemudian filtrat dievaporasi menggunakan rotary evaporator vacum pada suhu $55^{\circ} \mathrm{C}$ dengan kecepatan konstan (4 rpm). Proses evaporasi dihentikan setelah pelarut metanol teruapkan semua sehingga didapatkan oleoresin dalam bentuk pasta.

\section{Rancangan Percobaan}

Rancangan penelitian menggunakan pola Response Surface Methodology (RSM) dengan menggunakan 3 faktor yaitu:

- Faktor I : variasi ukuran bahan $(20,50$, dan 80 mesh)

- Faktor II : variasi suhu $\left(45,55\right.$, dan $\left.65{ }^{\circ} \mathrm{C}\right)$

- Faktor III : variasi waktu kontak $(2,4$, dan 6 jam)

Pola pengkodean faktor I, faktor II, dan faktor III dicantumkan dalam Tabel 1 serta dalam Tabel 2 akan dijelaskan mengenai desain penelitian yang menggunakan pendekatan desain Box-Benhken.

\section{HASIL DAN PEMBAHASAN}

Oleoresin kulit kayu manis umumnya dihasilkan dengan proses ekstraksi, baik ekstraksi secara langsung maupun gabungan antara proses destilasi dan ekstraksi. Pada ekstraksi secara langsung oleoresin diperoleh dengan cara mengekstrak bubuk limbah destilasi kulit kayu manis dengan pelarut, sedangkan oleoresin yang diperoleh dengan gabungan proses destilasi dan ekstraksi adalah dengan cara mengambil minyak atsirinya terlebih dahulu melalui proses destilasi, kemudian residu atau ampas hasil destilasi diekstrak dengan menggunakan pelarut.

Akan tetapi sebelum diekstrak dengan menggunakan pelarut, ampas atau residu tersebut diubah kedalam bentuk bubuk terlebih dahulu yang disesuaikan dengan ukuran yang telah ditentukan. Pembuatan bubuk limbah destilasi kulit kayu manis dimulai dengan proses pengeringan ampas atau residu hasil destilasi, kemudian ampas atau residu dikeringanginkan untuk mengurangi kadar airnya sebelum dilakukan proses penepungan. Salah satu parameter utama untuk menentukan kualitas bubuk kulit kayu manis adalah dengan menentukan kadar airnya.

Penentuan kadar air dilakukan sebelum proses ekstraksi limbah destilasi kulit kayu manis yang berfungsi menyatakan kandungan zat dalam tumbuhan sebagai persen kering, mengetahui cara penyimpanan sampel yang baik, dan menghindari pengaruh mikroba. Menurut Winarno (1997), sampel yang baik disimpan dalam jangka panjang adalah yang memiliki kadar air kurang dari $10 \%$. Kadar air serbuk kulit kayu manis adalah $8,91 \%$. Sampel tersebut memenuhi 
Tabel 3 Hasil Analisis Rendemen Oleoresin Limbah Destilasi Kulit Kayu Manis

\begin{tabular}{ccccc}
\hline Run & Ukuran (mesh) & $\begin{array}{c}\text { Suhu }\left({ }^{\circ} \mathrm{C}\right) \\
\mathrm{X}_{2}\end{array}$ & $\begin{array}{c}\text { Waktu (Jam) } \\
\mathrm{X}_{3}\end{array}$ & $\begin{array}{c}\text { Rendemen } \\
(\%)\end{array}$ \\
\hline 1 & $20(-1)$ & $45(-1)$ & $4(0)$ & 11,508 \\
2 & $20(-1)$ & $65(1)$ & $4(0)$ & 13,872 \\
3 & $80(1)$ & $45(-1)$ & $4(0)$ & 12,536 \\
4 & $80(1)$ & $65(1)$ & $4(0)$ & 15,541 \\
5 & $20(-1)$ & $55(0)$ & $2(-1)$ & 11,671 \\
6 & $20(-1)$ & $55(0)$ & $6(1)$ & 13,193 \\
7 & $80(1)$ & $55(0)$ & $2(-1)$ & 12,632 \\
8 & $80(1)$ & $55(0)$ & $6(1)$ & 11,411 \\
9 & $50(0)$ & $45(-1)$ & $2(-1)$ & 11,551 \\
10 & $50(0)$ & $45(-1)$ & $6(1)$ & 12,771 \\
11 & $50(0)$ & $65(1)$ & $2(-1)$ & 12,164 \\
12 & $50(0)$ & $65(1)$ & $6(1)$ & 11,005 \\
13 & $50(0)$ & $55(0)$ & $4(0)$ & 10,743 \\
14 & $50(0)$ & $55(0)$ & $4(0)$ & 11,272 \\
15 & $50(0)$ & $55(0)$ & $4(0)$ & 11,510 \\
\hline
\end{tabular}

karakteristik mutu bubuk kulit kayu manis yang dinyatakan dalam SNI 01-3714-1995 (Kulit Kayu Manis Bubuk) yang menunjukkan bahwa kadar air bubuk kulit kayu manis maksimal 12\%. Penentuan kadar air ini penting untuk dilakukan dikarenakan air merupakan senyawa polar sehingga memungkinkan dapat mengikat senyawa polar dalam hal ini berupa senyawa sinamaldehid, sehingga dapat menurunkan kandungan sinamaldehid dalam oleoresin yang diperoleh, bilamana dalam bubuk limbah destilasi kulit kayu manis memiliki kandungan air yang tinggi.

\section{Optimasi Rendemen Oleoresin Kayu Manis}

Oleoresin limbah destilasi kulit kayu manis yang didapatkan dari proses ekstraksi secara maserasi yang kemudian dilanjutkan dengan proses evaporasi lalu dihitung rendemennya, hal ini dimaksudkan untuk membandingkan hasil yang diperoleh pada tiap-tiap sampel yang dianalisis. Rendemen merupakan kadar kandungan oleoresin di dalam rimpang yang dinyatakan dengan persen. Rendemen oleoresin dinyatakan dalam berat per berat, sehingga perhitungannya berdasarkan berat kering.

Tabel 3 merupakan desain penelitian yang menggunakan pendekatan desain Box-

Behnken. Angka -1, 0, dan 1 merupakan simbol yang menunjukan nilai dari variabel. Angka -1 menunjukkan nilai variabel terendah, angka 0 menunjukkan nilai variabel medium dan angka 1 menunjukkan nilai variabel tertinggi. Range antara $-1,0$ dan 1 harus sama.

Hasil penghitungan selanjutnya dianalisis menggunakan Matlab 7.0 untuk mengetahui rendemen optimum yang ditampilkan melalui Response Surface Methodology (RSM). Untuk menyelesaikan masalah metodologi respon permukaan biasanya digunakan model matematika polinomial orde satu atau orde dua. Persamaan umum untuk model matematika polinomial adalah sebagai berikut:

$\mathrm{Y}=\mathrm{b} 0+\mathrm{b} 1 \mathrm{x} 1+\mathrm{b} 2 \mathrm{x} 2+\ldots+\mathrm{bn} \cdot \mathrm{xn}+\square$ (orde pertama)

$\hat{Y}=b_{0}+b_{1} x_{1}+\ldots+b_{n} x_{n}+b_{11} x_{1}^{2}+\ldots+$ $b_{n n} x_{n}^{2}+b_{12} x_{1} x_{2}+\ldots+b_{n-1 . n} x_{n-1} x_{n}$ (orde dua)

Dalam penelitian ini digunakan persamaan menggunakan orde dua dan karena menggunakan model Box-Behnken maka digunakan tiga faktor yaitu, ukuran $\left(\mathrm{X}_{1}\right) 20$ sampai 80 mesh, suhu dari 45 sampai $65^{\circ} \mathrm{C}\left(\mathrm{X}_{2}\right)$, dan waktu ekstraksi $\left(\mathrm{X}_{3}\right)$ dari 2 hingga 6 jam. 
Pengaruh Ukuran dan Suhu terhadap Rendemen Oleoresin Limbah Destilasi Kayu Manis

Hasil optimasi menggunakan Matlab 7.0 yang menginteraksikan antara faktor ukuran $\left(\mathrm{X}_{1}\right)$ dan suhu $\left(\mathrm{X}_{2}\right)$ didapat fungsi respon yaitu:

$\mathrm{Y}=11,1756+0,2344 \mathrm{X}_{1}+0,5271 \mathrm{X}_{2}+1,2718$ $\mathrm{X}_{1}{ }^{2}+0,9178 \mathrm{X}_{2}^{2}+0,1600 \mathrm{X}_{1} \mathrm{X}_{2}$

Persamaan tersebut menghasilkan titik stasioner $\quad(-0,0745 ; \quad-0,2807 ; 11,0929)$. Berdasarkan titik stationer yang didapat, diketahui bahwa rendemen yang optimum yaitu $11,093 \%$ yang didapat pada ukuran 47,765 mesh dan suhu $52,193{ }^{\circ} \mathrm{C}$.

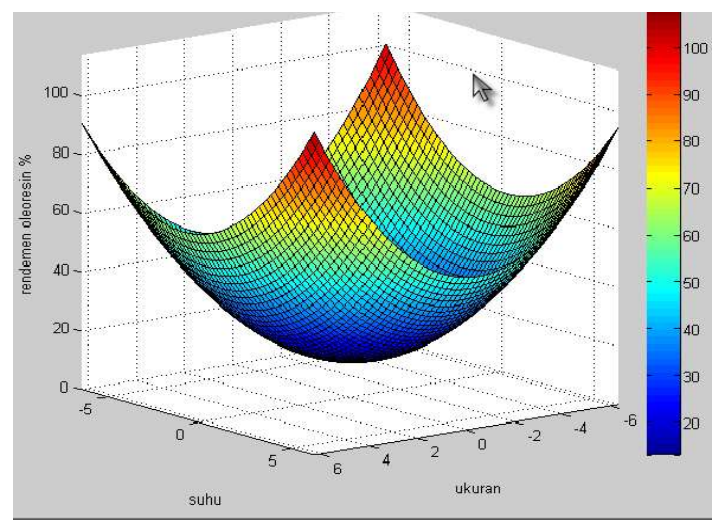

(a)

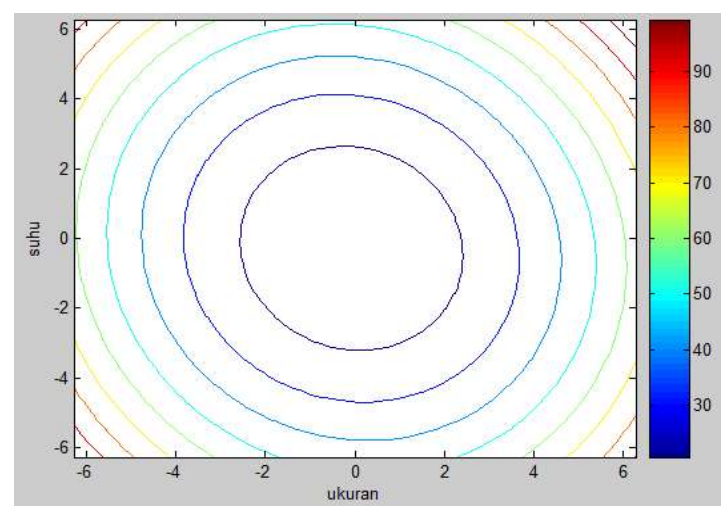

(b)

Gambar 1 Grafik 3D Optimasi Rendemmen Oleoresin Limbah Destilasi Kayu Manis Terhadap Ukuran dan Suhu, (a) Plot Surface, (b) Plot Contour.

Hasil analisis eigen value seperti disajikan pada Tabel 4 diperoleh nilai positif. Hal ini berarti bahwa kondisi optimum titik pusat $\left(\mathrm{X}_{0}\right)$ berada pada titik minimum di
Tabel 4 Analisis Nilai Eigen Value

\begin{tabular}{lllll}
\hline Variabel & $\begin{array}{l}\text { Kondisi } \\
\text { Optimum } \\
\text { Rendemen }\end{array}$ & Nilai Eigen \\
\hline X1 & $-0,0745$ & 11,093 & 1,289 & 0 \\
X2 & $-0,2807$ & & 0 & 0,901 \\
\hline
\end{tabular}

mana faktor yang berpengaruh pada rendemen oleoresin menunjukkan respon yang sama, sehingga masing-masing faktor memberikan respon yang minimum.

Berdasarkan pada Tabel 4 dapat dibuat kurva dan kontur seperti disajikan dalam Gambar 1. Pada gambar tersebut terlihat bahwa semakin besar ukuran mesh atau berarti semakin kecil ukuran partikel maka rendemen oleoresin yang dihasilkan akan semakin besar.Menurut Goldman (1949), kehalusan bahan yang sesuai akan menjadikan ekstraksi berlangsung dengan sempurna.Hal ini disebabkan karena ukuran yang semakin kecil atau halus akan memiliki permukaan bahan yang semakin luas, sehingga memungkinkan oleoresin dapat terekstrak secara optimal oleh pelarut. Hal ini selaras menurut Komara dalam Samuel (2004) pengecilan ukuran akan memperluas bidang kontak antara bubuk dan pelarut sehingga semakin banyak oleoresin yang dapat diekstrak.

Faktor suhu juga berpengaruh terhadap rendemen oleoresin limbah destilasi kayu manis. Menurut Sujarwadi (1996) dalam Fuad Muhiedin (2008) ekstraksi akan lebih cepat dilakukan pada suhu tinggi.

\section{Pengaruh Ukuran dan Waktu Ekstraksi terhadap Rendemen Oleoresin Limbah Destilasi Kayu Manis}

Hasil Optimasi menggunakanMatlab 7.0 yang menginteraksikan antara faktor ukuran $\left(\mathrm{X}_{1}\right)$ dan waktu $\left(\mathrm{X}_{3}\right)$ didapatkan fungsi respon yaitu:

$\mathrm{Y}=11,1756+0,2344 \mathrm{X}_{1}+0,0453 \mathrm{X}_{3}+1,2718$ $\mathrm{X}_{1}^{2}-0,2200 \mathrm{X}_{3}^{2}-0,6858 \mathrm{X}_{1} \mathrm{X}_{3}$

Persamaan tersebut menghasilkan titik stasioner $\quad(-0,0453 ; 0,1736 \quad ; 11,1742)$. Berdasarkan titik stationer yang didapat, diketahui bahwa rendemen yang optimum yaitu $11,1742 \%$ yang didapat pada ukuran 48,641 mesh dan waktu 4,347 jam. 


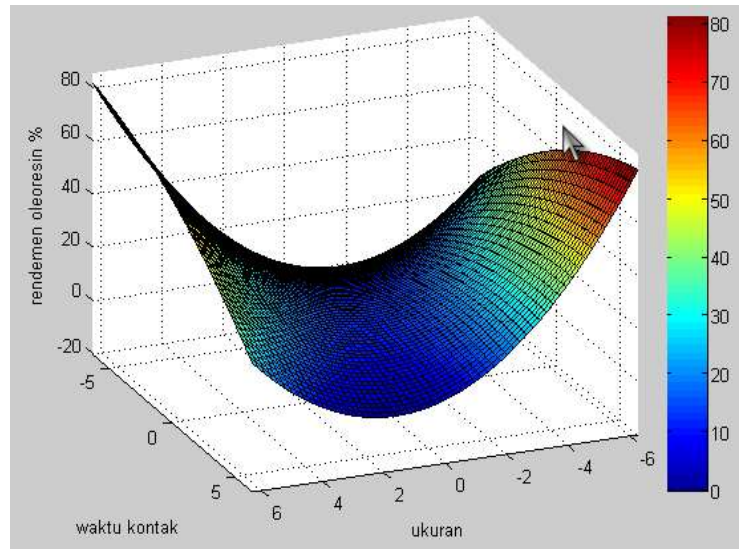

(a)

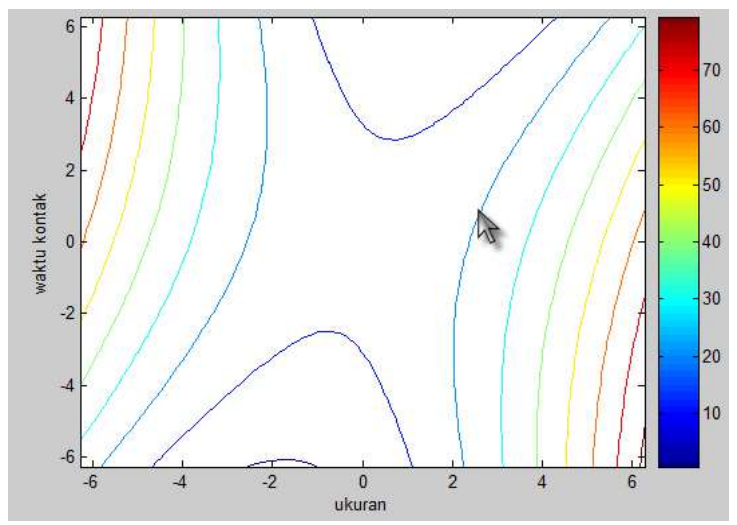

(b)

Gambar 2 Grafik 3D Optimasi Rendemmen Oleoresin Kayu Manis Terhadap Ukurandan waktu, (a) Plot Surface, (b) Plot Contour

Tabel 5 Analisis Nilai Eigen Value

\begin{tabular}{ccccc}
\hline Variabel & \multicolumn{1}{c}{$\begin{array}{c}\text { Kondisi } \\
\text { Optimum } \\
\text { Rendemen }\end{array}$} & \multicolumn{2}{c}{ Nilai Eigen } \\
X1 & $-0,045$ & 11,174 & 1,347 & 0 \\
X2 & 0,174 & & 0 & $-0,295$ \\
\hline
\end{tabular}

Pada model permukaan respon tersebut dapat dilihat bahwa solusi optimasi yang dihasilkan adalah berbentuk saddle point atau pelana. Dikarenakan model tersebut berbentuk pelana maka tidak dapat memberikan informasi yang optimal sehingga kondisi perlakuan yang diharapkan akan menghasilkan rendemen oleoresin tertinggi tidak dapat ditentukan secara langsung. Penentuan kondisi optimum dapat dilakukan dengan menganalisa tingkat pengaruh waktu kontak dan ukuran terhadap permukaan respon rendemen.

Hasil analisis eigen value seperti disajikan pada Tabel 5 diperoleh nilai positif dan negatif. Hal ini berarti bahwa kondisi optimum titik pusat $\left(\mathrm{X}_{0}\right)$ berada pada titik minimum dan maksimum dimana faktor yang berpengaruh pada rendemen oleoresin menunjukkan respon yang berbeda, sehingga masing-masing faktor memberikan respon yang berbeda pula.

$$
\text { Pada ekstraksi oleoresin }
$$
meningkatnya rendemen yang dihasilkan selaras dengan lamanya waktu kontak selama ekstraksi seperti yang terlihat pada Gambar 2. Hal ini disebabkan karena semakin lama waktu ekstraksi, mengakibatkan waktu kontak antara pelarut dan bahan baku semakin lama pula. Sehingga proses penetrasi pelarut kedalam sel bahan baku akan semakin baik, dan menyebabkan semakin banyaknya senyawa yang berdifusi keluar sel (Basalmah,2006).

Menurut Komara dalam Samuel (2004) pengecilan ukuran akan memperluas bidang kontak antara bubuk dan pelarut sehingga semakin banyak oleoresin yang dapat diekstrak.

\section{Pengaruh Suhu dan Waktu Ekstraksi terhadap Rendemen Oleoresin Limbah Destilasi Kayu Manis}

Hasil Optimasi menggunakanMatlab 7.0 yang menginteraksikan antara faktor suhu $\left(\mathrm{X}_{2}\right)$ dan waktu $\left(\mathrm{X}_{3}\right)$ didapat fungsi respon yaitu:

$\mathrm{Y}=11,1756 \quad+0,5271 \mathrm{X}_{2} \quad+0,0453 \mathrm{X}_{3}$ $+0,9178 \mathrm{X}_{2}^{2}-0,2200 \mathrm{X}_{3}^{2}-0,5947 \mathrm{X}_{2} \mathrm{X}_{3}$

Persamaan tersebut menghasilkan titik stasioner $\quad(-0,1765 ; 0,3415 \quad ; 11,137)$. Berdasarkan titik stationer yang didapat, diketahui bahwa rendemen yang optimum yaitu $11,137 \%$ yang didapat pada suhu53,235 ${ }^{\circ} \mathrm{C}$ dan waktu4,683 jam.

Pada model permukaan respon tersebut dapat dilihat bahwa solusi optimasi yang dihasilkan adalah berbentuk saddle pointatau pelana. Dikarenakan model tersebut berbentuk pelana maka tidak dapat memberikan informasi yang optimal sehingga kondisi perlakuan yang diharapkan akan menghasilkan rendemen oleoresin tertinggi tidak dapat ditentukan secara langsung. Penentuan kondisi optimum dapat dilakukan dengan menganalisa tingkat pengaruh waktu 


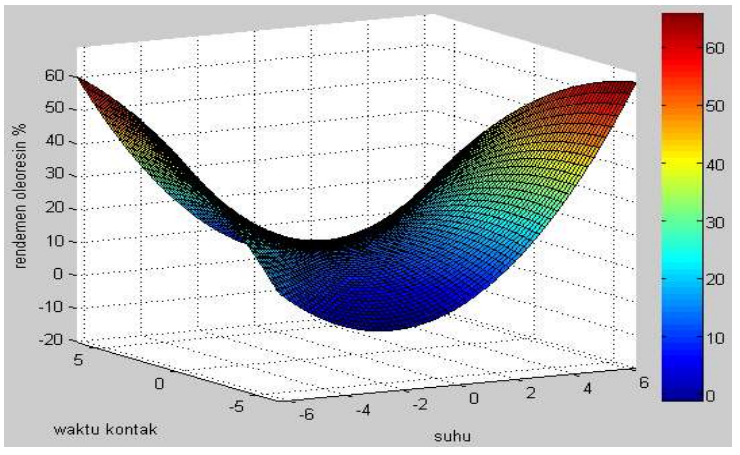

(a)

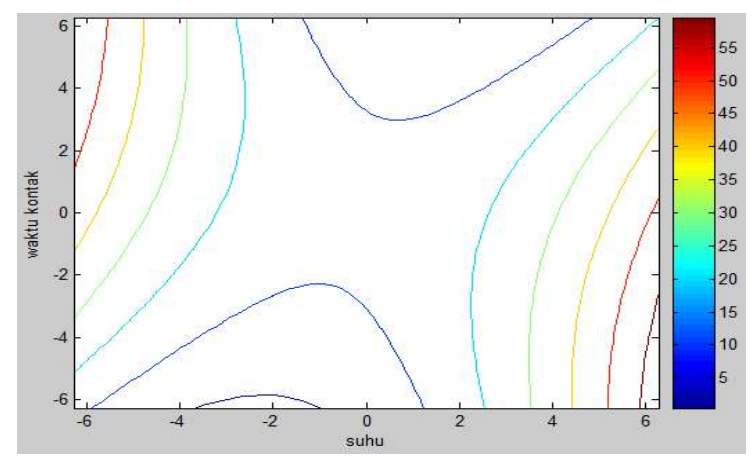

(b)

Gambar 3 Grafik 3D Optimasi Rendemen Oleoresin Limbah Destilasi Kayu Manis Terhadap suhu dan waktu, (a) Plot Surface, (b) Plot Contour

Tabel 6 Analisis Nilai Eigen Value

\begin{tabular}{ccccc}
\hline Variabel & $\begin{array}{c}\text { Kondisi } \\
\text { optimum } \\
\text { rendemen }\end{array}$ & Nilai eigen \\
\hline $\mathrm{X} 1$ & $-0,177$ & 11,137 & 0,991 & 0 \\
$\mathrm{X} 2$ & 0,342 & 1,137 & $-0,293$ \\
\hline
\end{tabular}

kontak dan suhu terhadap permukaan respon rendemen.

Hasil analisis eigen value seperti disajikan pada Tabel 6 diperoleh nilai positif dan negatif. Hal ini berarti bahwa kondisi optimum titik pusat $\left(\mathrm{X}_{0}\right)$ berada pada titik minimum dan maksimum di mana faktor yang berpengaruh pada rendemen oleoresin menunjukkan respon yang berbeda, sehingga masing-masing faktor memberikan respon yang berbeda pula.

Menurut Sundari (2002) temperatur berpengaruh pada energi kinetik molekul. Semakin tinggi temperatur mengakibatkan naiknya energi kinetik oleoresin dan molekul pelarut, sehingga gaya tarik menarik antar molekul oleoresin dan molekul pelarut bertambah. Akibatnya laju difusi oleoresin ke dalam pelarut juga meningkat.

Pada ekstraksi oleoresin meningkatnya rendemen yang dihasilkan selaras dengan lamanya waktu kontak selama ekstraksi seperti yang terlihat pada Gambar 3.Hal ini disebabkan karena semakin lama waktu ekstraksi, mengakibatkan waktu kontak antara pelarut dan bahan baku semakin lama pula. Sehingga proses penetrasi pelarut kedalam sel bahan baku akan semakin baik, dan menyebabkan semakin banyaknya senyawa yang berdifusi keluar sel (Basalmah,2006).

Fungsi respon yang didapat dari interaksi ketiga faktor yaitu ukuran $\left(\mathrm{X}_{1}\right)$, suhu $\left(\mathrm{X}_{2}\right)$, dan waktu $\left(\mathrm{X}_{3}\right)$ yaitu :

$$
\begin{aligned}
& \mathrm{Y}=11,1756+0,2344 \mathrm{X}_{1}+0,5271 \mathrm{X}_{2} \\
& +0,0453 \mathrm{X}_{3}+1,2718 \mathrm{X}_{1}^{2}+0,9178 \mathrm{X}_{2}^{2}- \\
& 0,2200 \mathrm{X}_{3}^{2}+0,1600 \mathrm{X}_{1} \mathrm{X}_{2}-0,6858 \mathrm{X}_{1} \mathrm{X}_{3}- \\
& 0,5947 \mathrm{X}_{2} \mathrm{X}_{3}
\end{aligned}
$$

Dari persamaan tersebut menghasilkan titik stationer $(0,0089 ;-0,1801$; $0,3326 ; 11,137)$. Berdasarkan titik stationer yang didapat, diketahui bahwa rendemen yang optimum yaitu $11,137 \%$ yang didapat pada ukuran partikel sebesar50,267 mesh, suhu ekstraksi53,199 ${ }^{\circ} \mathrm{C}$, dan waktu ekstraksi 4,6652 jam.

\section{Karakteristik Mutu Oleoresin Kulit Kayu Manis}

Pada optimasi rendemen oleoresin limbah destilasi kulit kayu manis dengan analisis menggunakan Matlab 7.0 diperoleh perlakuan optimum yaitu ukuran partikel 50,267 mesh, suhu ekstraksi $53,199^{\circ} \mathrm{C}$, dan waktu ekstraksi 4,6652 jam. Perlakuan itulah yang menjadi dasar pada tahap selanjutnya yang kemudian akan dilakukan pengujian tehadap karakteristik mutu daripada oleoresin kulit kayu manis.

Bubuk kulit kayu manis ukuran 50 mesh diekstrak pada suhu $55{ }^{\circ} \mathrm{C}$ selama 4 jam. Selanjutnya ekstrak bubuk limbah destilasi kulit kayu manis dievaporasi menggunakan rotary evaporator vacum hingga menjadi cairan kental yang disebut oleoresin. Rendemen oleoresinlimbah destilasi kulit kayu manis yang diperoleh sebesar 12,564\%. Oleoresin limbah destilasi kulit kayu manis ini yang selanjutnya 
dilakukan pengujian karakteristik mutu oleoresin limbah destilasi kulit kayu manis, yang meliputi kadar minyak atsiri, kadar sinamaldehid dan sisa pelarut ( kadar metanol).

\section{a. Kadar Sinamaldehid Oleoresin Limbah Destilasi Kayu Manis}

Sinamaldehid merupakan komponen utama yang terdapat dalam minyak atsiri maupun oleoresin kulit kayu manis. Senyawa sinamaldehid merupakan cairan berwarna kuning, mempunyai aroma khas, memiliki rasa manis dan pedas, sedikit larut dalam air, larut dalam alkohol dan eter (Djlsbar, 1996). Jumlah kadar sinamaldehid hasil ekstraksi limbah destilasi kulit kayu manis dapat terlihat pada Gambar 4.

Terlihat pada Gambar 4 hasil analisis dengan GC-MS, diperoleh persen sinamaldehid hanya sebesar $12,222 \%$ dimana waktu retensinya 12.272 menit dengan massa molekul 131,05. Rendahnya kandungan sinamaldehid dikarenakan dalam oleoresin hanya mengandung sedikit kandungan minyak yaitu hanya sebesar 7,554\%.Kadar sinamaldehid oleoresin hampir sama dengan jumlah sinamaldehid terkandung dalam minyak, karena oleoresin yang terekstrak umumnya mengandung sejumlah minyak (Solehudin, 2001).

Pemanasan dapat menurunkan sinamaldehid oleoresin. Hal ini disebabkan pada proses ekstraksi dengan perlakuan pemanasan sejumlah komponen volatil (termasuk sinamaldehid) mengalami penguapan sehingga jumlah komponen sinamaldehidnya lebih rendah dibandingkan tanpa pemanasan.

Tinggi rendahnya kadar sinamaldehid yang diperoleh dipengaruhi oleh beberapa faktor antara lain budidaya, tempat tumbuh dan jenis/mutu kayu manis yang digunakan serta faktor teknis saat dilakukan ekstraksi, seperti sifat pelarut yang digunakan, suhu dan lama ekstraksi yang dilakukan dan derajat kehalusan bahan (Yusmanetti, 2007).

Hasil analisa oleoresin menggunakan GC-MS ditunjukkan dalam Kromatogram pada Gambar 4.

Pada Gambar 4 kromatogram GC-MS sinamaldehid dari oleoresin, senyawa sinamaldehid berada pada puncak ke- $3(\mathrm{RT}=$ 12.272) dengan massa molekul 131. Dari hasil analisa GC-MS didapatkan kadar sinamldehid sebesar 12,22\%. Senyawa lainnya yang terkandung didalamnya dapat terlihat pada Tabel 7.

\section{b. Kadar Minyak Atsiri Oleoresin Limbah Destilasi Kayu Manis}

Oleoresin kulit kayu manis adalah suatu cairan kental berwarna coklat kemerahan yang mengandung minyak atsiri, minyak lemak, warna, resin dan mempunyai aroma yang pedas. Senyawa aromatik yang terkandung dalam oleoresin adalah camphene, linalool, alpha fenchene, alphapinene, beta-pinene, camphor, 1;8 cineole, alpha-terpineol, alpha-capaene, cinamaldehyde, cinnamyl alcohol, cinnamic acid, cinnamyl acetat, eugenol, methyl eugenol, coumarin, alpha-phenyl alcohol (Kenneth, 1985).

Minyak atsiri merupakan salah satu komponen yang dapat terekstrak dalam proses menghasilkan oleoresin. Minyak atsiri ini merupakan komponen volatil dari komponen yang dikandung oleh oleoresin. Kadar minyak atsiri yang dikandung oleh oleoresin hasil ekstraksi hanya sebesar 7,554 $\%$. Hasil yang diperoleh ini jauh dari standar spesifikasi jumlah minimal minyak atsiri dalam oleoresin menurut FDA. Dalam Sundari (2002) salah satu spesifikasi oleoresin dalam Food Drug Administration (FDA) kadar minyak atsiri oleoresin minimal $25 \%$.

Hal ini dikarenakan bahan baku awal oleoresin kulit kayu manis merupakan ampas proses destilasi, dimana dalam proses destilasi tersebut kandungan minyak atsiri dari kulit kayu manis sudah diambil terlebih dahulu sehingga memungkinkan kandungan minyak atsiri dalam oleoresin cenderung memberikan hasil yang rendah. Pemanasan juga mempengaruhi kandungan minyak atsiri dari oleoresin limbah destilasi kulit kayu manis. Pemanasan menyebabkan beberapa komponen minyak atsiri yang mudah menguap hilang sehingga jumlah minyak atsiri yang dikandung oleh oleoresin lebih sedikit. Selain itu pada saat proses pemisahan pelarut menggunakan vacum evaporator yang 


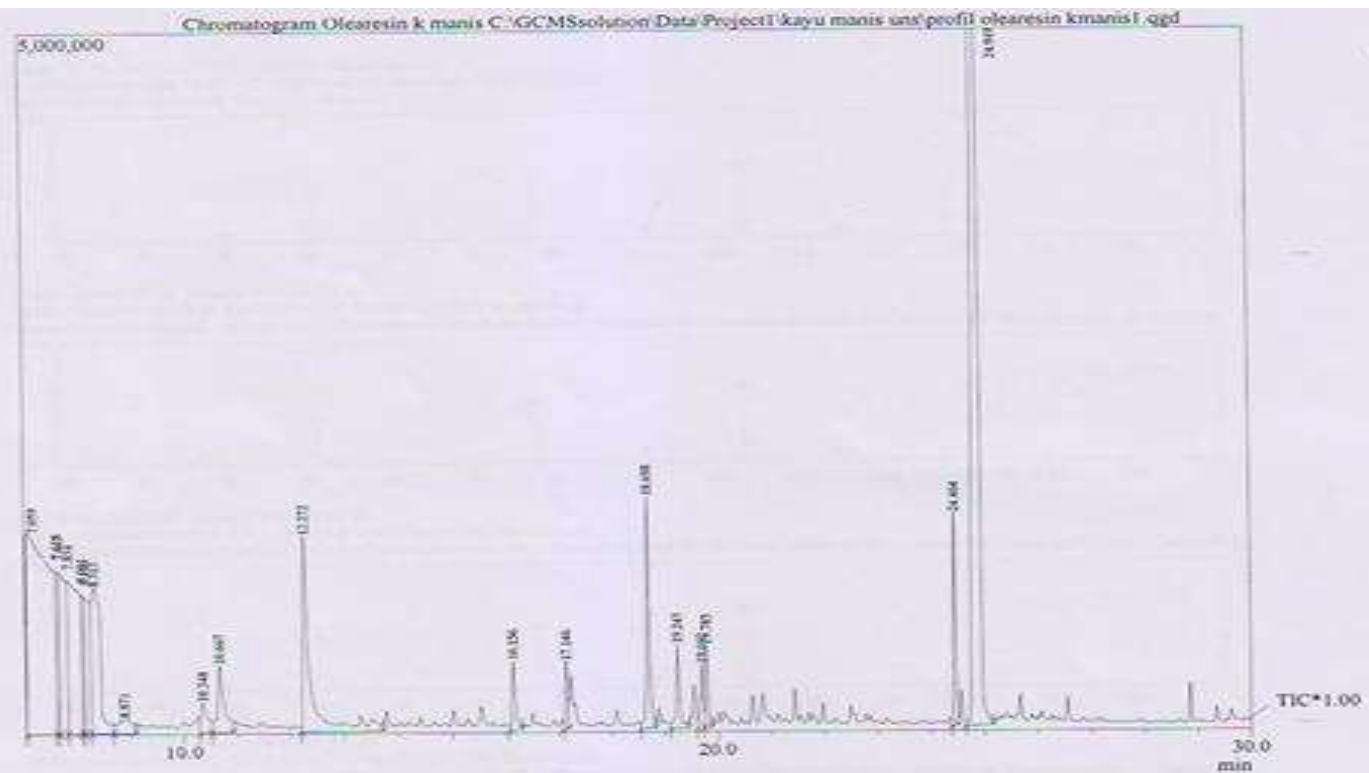

Gambar 4 Kromatogram GC Oleoresin Limbah Destilasi Kayu Manis

Tabel 7 Senyawa pada Oleoresin Limbah Destilasi Kayu Manis Hasil GC MS

\begin{tabular}{ccccc}
\hline Peak & Waktu Retensi & Area & \% Area & Nama \\
\hline 1 & 10.348 & 1775318 & 1,709 & Terpinene-4-ol \\
2 & 10.667 & 4229159 & 4,073 & Linalyl propionate \\
3 & 12.272 & 12688932 & 12,222 & Cinnamyldehyde \\
4 & 16.156 & 2004389 & 1,931 & Alpha-Copaene \\
5 & 17.146 & 1755485 & 1,691 & Cinnamyl acetate \\
6 & 18.698 & 6269293 & 6,038 & alpha-Curcumene \\
7 & 19.243 & 2630724 & 2,534 & alpha-Muurolene \\
8 & 19.697 & 1807539 & 1,741 & Dodecanoic acid \\
9 & 19.785 & 1945133 & 1,873 & delta-Cadinene \\
10 & 24.464 & 4665458 & 4,493 & Cyclohexanol \\
11 & 24.949 & 64052228 & 61,693 & Benzoic acid \\
\hline
\end{tabular}

mana saat pompa sirkulasi tidak bekerja sesuai dengan semestinya menyebabkan kondisi kevakuman proses tidak optimum. Dengan demikian waktu proses menjadi lama dan menyebabkan hilangnya sebagian besar minyak atsiri.

\section{c. Sisa Pelarut Oleoresin Limbah Destilasi Kayu Manis ( Kadar Metanol)}

Sisa pelarut merupakan hal yang sangat penting dalam proses menghasilkan oleoresin, karena sisa pelarut ini akan menentukan mutu oleoresin yang dihasilkan dan penerimaan konsumen terhadap oleoresin tersebut.

MenurutMoestafa (1981) dalam Sutianik (1999) ekstraksi oleoresin harus menggunakan pelarut yang mudah menguap, sebab jika oleoresin masih terdapat pelarut yang berlebihan, maka harus diuapkan kembali sampai memenuhi standar. Pada umumnya standar yang dipakai adalah batasan sisa jumlah pelarut yang tertinggal pada bahan makanan menurut Food and Drug Administration (FDA).

Kadar sisa pelarut diharapkan dalam oleoresin tersebut hanya mengandung jumlah sisa pelarut yang sangat sedikit. Faktor yang mempengaruhi besar kecilnya sisa pelarut adalah proses evaporasi dalam pemisahan oleoresin dengan pelarut. Proses evaporasi ini dinyatakan selesai jika tidak ada lagi pelarut yang menetes, pada proses evaporasi ini ada kemungkinan sejumlah komponen masih menempel pada oleoresin yang dihasilkan sehingga pelarut yang masih menempel ini dinyatakan sebagai sisa pelarut. Jumlah sisa 
pelarut yang disarankan oleh FDA dapat terlihat dalam Tabel 8.

Tabel 8 Residu Beberapa Jenis Pelarut

\begin{tabular}{ccc}
\hline Pelarut & $\begin{array}{c}\text { Titik didih } \\
\left({ }^{\circ} \mathrm{C}\right)\end{array}$ & $\begin{array}{c}\text { residu } \\
(\mathrm{ppm})\end{array}$ \\
\hline aseton & 56,5 & 30 \\
metanol & 64,7 & 50 \\
heksan & 69 & 25 \\
isopropil alkohol & 82,3 & 50 \\
etil klorida & 83,5 & 30 \\
\hline
\end{tabular}

Sumber : Moestafa (1981)

Pengujian kadar metanol oleoresin kayu manis menggunakan gas kromatografi (GC). Sampel oleoresin dilarutkan menggunakan aquades, lapisan atas yang bening diambil untuk selanjutnya diinjeksi pada alat GC.

Hasil pengujian menunjukkan bahwa kadar metanol oleoresin kayu manis sebesar 1,66 ppm. Hal ini memenuhi standar batasan sisa jumlah pelarut metanol dalam bahan makanan menurut FDA sebesar 50 ppm.

\section{KESIMPULAN}

Kesimpulan yang diperoleh dari penelitian ini adalah sebagai berikut:

1. Rendemen optimum oleoresin limbah destilasi kayu manis adalah sebesar11,137 $\%$ yang didapatkan pada kondisi ukuran partikel50,267 mesh, suhu ekstraksi $53,199{ }^{\circ} \mathrm{C}$, dan waktu ekstraksi 4,6652 jam.

2. Karakteristik mutu oleoresin limbah destilasi kayu manis pada rendemen optimum adalah kadar sinamaldehid $12,22 \%$, kadar minyak atsiri 7,554 \% dan kadar sisa pelarut ( kadar metanol ) 1,66 ppm.

\section{DAFTAR PUSTAKA}

Anonim ${ }^{\mathrm{a}}$.2007.Cinnamaldehyde.http://en.wiki pedia.org/wiki/File:Zimtaldehydcinnama ldehyde.svg diakses 18 Oktober 2011

Anonim ${ }^{\text {b.2010.Kayu Manis (Cinnamomum }}$ burmanni).

timpakul.web.id/2010/10/kayumanis.jpg 2010. diakses 18 Oktober 2011.
Azima,Fauzan. 2004. Kayu manis Cegah Aterosklorosis dan Kanker.Info Teknologi Pangan. http://ipb.ac.id/. Diakses pada 2 November 2011.

Basalmah, Rahmat Sulaeman. 2006. Optimalisasi Kondisi Ekstraksi Kurkuminoid Temulawak : Waktu, Suhu, Dan Nisbah. Skripsi. Departemen Kimia. Fakultas Matematika Dan Ilmu Pengetahuan Alam. Institut pertanian Bogor. Bogor

Komara, A. 1991.Mempelajari ekstraksi Oleoresin Dan Karakteristik Mutu Oleoresin dari Bagian Cabe Rawit.Dalam : Samuel, W. Pengaruh Jenis Pelarut dan Suhu terhadap Rendemen Oleoresin Temu Hitam.Skripsi. FTP. Universitas Brawijaya. Malang.

Nainggolan, Marnaek. 2008. sis]Isolasi Sinamaldehida dari Kulı миyu Manis (Cinnamomum burmanii). Sekolah Pasca Sarjana Universitas Sumatera Utara. Medan.

Muhiedin, Fuad. 2008. Efisiensi Proses Ekstraksi Oleoresin Lada Hitam Dengan Metode Ekstraksi Multi Tahap. Skripsi. Jurusan Teknologi Industri Pertanian. Fakultas Teknologi Pertanian. Universitas Brawijaya. Malang.

Pebrimadewi, Elma. 2011. Isolasi Sinamaldehid Dari Minyak Kulit Kayu MAnis Sebagai Antioksidan. Skripsi. Departemen Kimia. Fakultas Matematika Dan Ilmu Pengetahuan Alam. Institut pertanian Bogor. Bogor.

Ramadhan A.E dan H.A. Phaza. 2010. Pengaruh Konsentrasi Etanol, Suhu Dan Jumlah Stage Pada Ekstraksi Oleoresin Jahe (Zingiber Officinale Rosc) Secara Batch. Skripsi. Jurusan Teknik Kimia. Fakultas Teknik. Universitas Diponegoro. Semarang

Rismunandar. 1989. Kayu Manis. Penebar Swadaya. Jakarta.

Rismunandar dan F. B. Paimin. 2001. Kayu Manis : Budidaya dan Pengolahan (Edisi Revisi). Penebar Swadaya. Jakarta.

Sari, Yusmanetti. 2007. Kajian Proses Pengayaan Virgin Coconut Oil dengan Zat Pigmen dari Temulawak, Kunyit, 
Daun Suji, Daun Kunyit, serta Angkak dan Aplikasinya dalam Penggorengan Bahan Pangan. Skripsi. Departemen Ilmu dan Teknologi Pangan. Fakultas Teknologi Pertanian. Institut Pertanian Bogor.

[SNI] Standar Nasional Indonesia. 1995. Kulit Kayu Manis Bubuk SNI 01-37141995. Jakarta: Badan Standardisasi Nasional.

Solehudin, M. 2001. Ekstraksi Minyak dan Oleoresin dari Kulit Kayu Manis (Cinnamomum burmanii).Skripsi. Departemen Ilmu dan Teknologi Pangan. Fakultas Teknologi Pertanian. Institut Pertanian Bogor

Sudarmadji S., B. Haryono, Suhardi. 1997. Prosedur Analisa untuk Bahan Makanan dan Pertania (Edisi Keempat). Liberty. Yogyakarta.

Sullaswatty,Anny, Wuryaningsih, Sri Hartati, Haznan Abimanyu, dan Joddy A Laksono. 2001.Kajian Awal Hasil Ekstraksi Minyak dan Oleoresin dari Kulit Kayu Manis ( Cinnamomum burmanii Blume). Prosiding Seminar Nasional $X$ " Kimia Industri dan Lingkungan” Yogyakarta, 6-7 November 2001

Sumangat, Djajeng \& Ma'mun.Pengaruh Ukuran dan Susunan Bahan Baku Serta Lama Penyulingan Terhadap Rendemen dan Mutu Minyak Kayumanis Srilangka (Cinnamomun Zeylanicum).Buletin TRO Volume XIV No. 1, 2003.http://minyakatsiriindonesia.wordp ress.com/atsiri-kayu-manis/djajengsumangat-dan-ma $\%$ E2\%80\%99mun/. Diakses pada 19 Oktober 2011.

Sundari, Elmi. 2002. [Tesis Magister]Pengambilan Minyak Atsiri dan Pleoresin dari Kulit Kayu Manis. Departemen Teknik Kimia Program Pasca Sarjana Institut Teknologi Bandung. Bandung.

Sutianik. 1999. Pengaruh Suhu Pengeringan dan Ukuran Bahan Terhadap Rendemen Dan Mutu Oleoresin Jahe (Zingiber officinale, Roscoe) Skripsi.Fakultas Teknologi Pertanian. Institut Pertanian Bogor. Bogor.
Susmirah. 1981. Pengambilan Oleoresin Jahe dengan Cara Solvent Extraction. BBIHP. Bogor. 1981.

Wales, Jimmy. 2010. Kulit Manis. http://id.wikipedia.org/wiki/Kulit_manis. Diakses pada tanggal 19 Oktober 2011.

Wangsa, Rasdi dan Sri Nuryati. 2007. Status dan Potensi Pasar Kayu Manis Organik Nasional dan Internasional. Aliansi Organis Indonesia. Bogor.

Widjanarko S.B. 2008. Ekstraksi Oleoresin Atau Bahan Aktif Tumbuhan Dengan Pelarut.http://simonbwidjanarko .wordpress.com/2008/07/03/ekstraksiole oresin-atau-bahan-aktif-tumbuhandengan-pelarut/. Diakses pada tanggal 2 Januari 2011.

Winarno FG. 1997. Kimia Pangan dan Gizi. Jakarta: Gramedia Pustaka Utama

Wulandari, Yustina Wuri et al. 2003. Optimaization of Cinnamaldehyde Production from Cinnamon Leaf ( Cinamomum burmanii Nees ex $B$ I). Indonesian Food and Nutrition Progress,2003 Vol.10 no.2

Wuri, Yustina, Purnama Darmadji, dan Budi Rahardjo. 2004. Sifat Sensoris Minyak Atsiri Daun Kayu Manis (Cinnamomun burmanni Nees Ex Blume). Agrosains, 17 (3), Juli 2004. 